\title{
Calcifying coral abundance near low-pH springs: implications for future ocean acidification
}

\author{
E. D. Crook - D. Potts - M. Rebolledo-Vieyra • \\ L. Hernandez $\cdot$ A. Paytan
}

Received: 11 July 2011/Accepted: 1 November 2011 / Published online: 20 November 2011

(c) The Author(s) 2011. This article is published with open access at Springerlink.com

\begin{abstract}
Rising atmospheric $\mathrm{CO}_{2}$ and its equilibration with surface ocean seawater is lowering both the $\mathrm{pH}$ and carbonate saturation state $(\Omega)$ of the oceans. Numerous calcifying organisms, including reef-building corals, may be severely impacted by declining aragonite and calcite saturation, but the fate of coral reef ecosystems in response to ocean acidification remains largely unexplored. Naturally low saturation $(\Omega \sim 0.5)$ low $\mathrm{pH}(6.70-7.30)$ groundwater has been discharging for millennia at localized submarine springs (called "ojos") at Puerto Morelos, México near the Mesoamerican Reef. This ecosystem provides insights into potential long term responses of coral ecosystems to low saturation conditions. In-situ chemical and biological data indicate that both coral species richness and coral colony size decline with increasing proximity to low-saturation, low-pH waters at the ojo centers. Only three scleractinian coral species (Porites astreoides, Porites divaricata, and Siderastrea radians) occur in undersaturated waters at all ojos examined. Because these three species are rarely major contributors to Caribbean reef framework, these data may
\end{abstract}

Communicated by Environment Editor Prof. Rob van Woesik

Electronic supplementary material The online version of this article (doi:10.1007/s00338-011-0839-y) contains supplementary material, which is available to authorized users.

E. D. Crook - D. Potts - A. Paytan $(\square)$

Institute of Marine Science, University of California,

1156 High Street, Santa Cruz, CA 95064, USA

e-mail: apaytan@ucsc.edu

M. Rebolledo-Vieyra $\cdot$ L. Hernandez

Unidad de Ciencias del Agua (UCIA), Centro de Investigación

Científica de Yucatán, A.C., Calle 8 \# 39, Lote 1, Manzana 29,

S.M. 64, 77524 Cancún, Quintana Roo, México indicate that today's more complex frame-building species may be replaced by smaller, possibly patchy, colonies of only a few species along the Mesoamerican Barrier Reef. The growth of these scleractinian coral species at undersaturated conditions illustrates that the response to ocean acidification is likely to vary across species and environments; thus, our data emphasize the need to better understand the mechanisms of calcification to more accurately predict future impacts of ocean acidification.

Keywords Ocean acidification - Coral reefs . Calcification $\cdot$ Saturation state $\cdot$ Omega

\section{Introduction}

Atmospheric $\mathrm{CO}_{2}$ is currently on the rise, and its equilibration with surface seawater is expected to reduce the $\mathrm{pH}$ of the surface oceans by approximately $0.4 \mathrm{pH}$ units by year 2100 (Caldeira and Wickett 2005; Orr et al. 2005; Doney et al. 2009). Numerous calcifying organisms, including reefbuilding corals, may be severely impacted by this reduction in $\mathrm{pH}$, which will lower the aragonite and calcite saturation state $(\Omega)$ and make skeletal and shell formation for many organisms more difficult (Fine and Tchernov 2007; Anthony et al. 2008; Doney et al. 2009). Recent field studies in the Mediterranean and Papua New Guinea have demonstrated strong impacts of low $\mathrm{pH}$ related to volcanic $\mathrm{CO}_{2}$ vents on both individual organisms and community structure (Hall-Spencer et al. 2008; Cigliano et al. 2010; Dias et al. 2010; RodolfoMetalpa et al. 2010; Fabricius et al. 2011). However, additional field studies under different natural conditions are necessary to ascertain a wider range of potential long-term impacts of ocean acidification on communities and ecosystem processes (Doney et al. 2009; Riebesell et al. 2010). 
Table 1 Chemical measurements and calculations at centers of ojo discharge

\begin{tabular}{|c|c|c|c|c|c|c|c|}
\hline Date and site & $\mathrm{DIC} \pm 3 \mu \mathrm{mol} \mathrm{kg}^{-1}$ & $\mathrm{TA} \pm 2 \mu \mathrm{mol} \mathrm{kg}^{-1}$ & Salinity & Temp ${ }^{\circ} \mathrm{C}$ & $\mathrm{pH}$ & $\Omega_{\mathrm{cal}}$ & $\Omega_{\text {arag }}$ \\
\hline Control & 2,099 & 2,403 & 35.5 & 31.6 & 8.03 & 5.35 & 3.60 \\
\hline \multicolumn{8}{|l|}{ June 2009} \\
\hline Ojo Gorgos & 3,545 & 3,427 & 28.6 & 27.2 & 7.13 & 1.15 & 0.75 \\
\hline Ojo Norte & 3,122 & 3,113 & 28.7 & 27.0 & 7.23 & 1.28 & 0.84 \\
\hline Ojo Laja & 3,314 & 3,228 & 25.8 & 28.1 & 7.20 & 1.22 & 0.79 \\
\hline Ojo Mini & 4,246 & 3,771 & 25.9 & 27.2 & 6.74 & 0.50 & 0.32 \\
\hline Ojo H-10 Fractura & 2,773 & 2,740 & 30.5 & 29.2 & 7.24 & 1.30 & 0.86 \\
\hline Ojo Fractura & 3,996 & 3,864 & 26.7 & 30.4 & 7.10 & 1.45 & 0.96 \\
\hline \multicolumn{8}{|l|}{ November 2009} \\
\hline Ojo Gorgos (1) & 3,340 & 3,279 & 26.2 & 28.3 & 7.25 & 1.41 & 0.91 \\
\hline Ojo Gorgos (2) & 3,466 & 3,264 & 25.4 & 25.8 & 7.01 & $0.81 *$ & $0.54^{*}$ \\
\hline Ojo Laja & 3,473 & 3,392 & 26.9 & 28.3 & 7.21 & 1.35 & 0.88 \\
\hline Ojo Pargos (1) & 3,156 & 3,095 & 24.7 & 24.9 & 7.29 & 1.32 & 0.87 \\
\hline Ojo Pargos (2) & 3,178 & 3,109 & 25.2 & 25.2 & 7.26 & 1.28 & 0.82 \\
\hline Ojo Mini & 5,233 & 4,691 & 25.3 & 25.6 & 6.79 & $0.65^{*}$ & $0.41 *$ \\
\hline \multicolumn{8}{|l|}{ August 2010} \\
\hline Ojo Gorgos (1) & 3,194 & 3,097 & 29.6 & 27.2 & 7.14 & $1.38 *$ & $0.90^{*}$ \\
\hline Ojo Gorgos (2) & 3,326 & 2,996 & 29.6 & 27.2 & 6.77 & $0.75 *$ & $0.49 *$ \\
\hline Ojo Norte & 3,326 & 3,142 & 29.2 & 27.0 & 6.61 & 0.77 & 0.50 \\
\hline Ojo Laja & 3,187 & 3,027 & 28.7 & 27.5 & 7.02 & $0.91 *$ & $0.6^{*}$ \\
\hline Ojo Pargos (1) & 3,332 & 3,079 & 28.7 & 27.5 & 6.88 & $0.70 *$ & $0.46^{*}$ \\
\hline Ojo H-10 Fractura & 3,407 & 2,736 & 29.4 & 27.9 & 7.09 & $0.81 *$ & $0.54 *$ \\
\hline Ojo de Agua & 3,145 & 2,946 & 29.7 & 27.2 & 6.94 & $0.84 *$ & $0.55^{*}$ \\
\hline
\end{tabular}

Summary of chemical parameters measured over three sampling excursions (June 2009, November 2009, and September 2010) at the 10 ojos. Values reported are from the centers of discharge, and analytical measurement errors are indicated. Saturation values were calculated using the program $\mathrm{CO}_{2}$ Sys, unless noted by $(*)$, which indicates that measured calcium concentrations were higher than expected due to limestone dissolution. $\mathrm{CO}_{2}$ dissociation constants in $\mathrm{CO}_{2}$ Sys were calculated from Mehrbach et al. (1973), refit by Dickson and Millero (1987), and pH is reported on the total scale. In the case of $(*)$, a more conservative estimate of $\Omega$ is reported that accounts for these higher $\mathrm{Ca}^{2+}$ concentrations (see Fig. 3, Supplementary Material). Natural variability in water characteristics based on samples collected at different times during the sampling trips was approximately: TIC (7\%), TA (6\%), Salinity (6\%), and Temperature (4\%). Natural variability in calculated pH (total scale) and saturation levels using $\mathrm{CO}_{2}$ Sys at sites sampled multiple times were $\mathrm{pH}(2 \%)$ and $\Omega(20 \%)$. Continuous $\mathrm{pH}$ data are published in Hoffman et al. (2011), and nutrient concentrations are available upon request from the corresponding author

Along the eastern coast of the Yucatán Peninsula, México (Electronic Supplementary Material, ESM Fig. 1S), nearshore springs, referred to locally as "ojos," discharge naturally low-pH, low carbonate saturation groundwater $(\Omega=$ $\left.\left[\mathrm{Ca}^{2+}\right]\left[\mathrm{CO}_{3}{ }^{2-}\right] / \mathrm{K}_{\mathrm{sp}}\right)$. These highly localized springs are a natural feature of the karst terrain, have been continuously discharging water for millennia (Beddows et al. 2002), and have been the focus of many studies since the early 1990s (van Tussenbroek 1995; Ruiz-Renteria et al. 1998; Carruthers et al. 2005). Discharge from these "ojos" is markedly more acidic $(\mathrm{pH}=6.70-7.30$ total scale $)$ and less saturated ( $\Omega_{\text {arag }}=0.30-0.97$ at ojo centers $)$ than the surrounding ocean water $\left(\Omega_{\text {arag }}=3.60\right)$, and they occur in close proximity to one of the Caribbean's largest coral reef ecosystems (the Mesoamerican Barrier Reef). Thus, the ojos of the Yucatán Peninsula provide a natural laboratory for examining the long-term impacts of low saturation waters on specific organisms and the coastal ecosystem. Specifically, much can be learned from this site about the response of calcifying organisms exposed to reduce saturation states over time scales much longer than the life span of individual organisms. The conditions creating low-pH seawater at the ojos differ from those of the ocean acidification scenario: specifically, the discharging water at the ojos is derived from high $\mathrm{CO}_{2}$ concentrations associated with brackish water that has interacted with soil and limestone. It is thus characterized by low $\mathrm{pH}$, high $\mathrm{Ca}^{2+}$ (salinity normalized), high dissolved inorganic carbon (DIC), and high total alkalinity (TA). However, the organisms residing at the ojos have been exposed to low-pH and low aragonite saturation, as is predicted for future ocean acidification (Table 1), but the organisms are also exposed to high nutrients, high dissolved inorganic carbon, and high alkalinity that are not necessarily predicted in future oceans subjected to acidification. 
Yet, these environments provide an opportunity to study in situ community impacts on corals exposed to low carbonate saturation conditions and often extreme drops in $\mathrm{pH}$ for extended time intervals.

At least thirteen ojos lie approximately $500 \mathrm{~m}$ offshore within the National Maritime Park at Puerto Morelos, in a shallow lagoon approximately $5 \mathrm{~m}$ deep (ESM Fig. 1S). The ojos range from 10-m long "fractures" to small circular depressions (seeps) only a few centimeters across (ESM Fig, 2S). Based on monitoring over two and a half years (April 2008 to September 2010), discharge from the ojos is continuous with a combined discharge flux (estimated using excess ${ }^{224} \mathrm{Ra}$ measurements) reaching as high as $\sim 800,000 \mathrm{~m}^{3} \mathrm{~h}^{-1}$ (Derse et al. 2008). Discrete water samples taken during three different sampling events (June 2009, November 2009, and September 2010) indicate that the $\mathrm{pH}$ (and other water chemical characteristics) at each ojo center varied on tidal time scales. However, the water discharged at the ojo center remained undersaturated during all sampling events (Table 1). Continuous $\mathrm{pH}$ monitoring over 2 months using a SeapHOx sensor supports this conclusion (Hofmann et al. 2011). The relationship between water chemistry and benthic biota (identity, density, and size) was investigated at 10 ojos dominated by rocky substrates and characterized by similar temperature, salinity, light, and $\mathrm{pH}$ conditions over the three different sampling events. We report the calculated saturation states (Pierrot et al. 2006) based on measured DIC, TA, and nutrient concentrations for each discrete sample using $\mathrm{CO}_{2}$ Sys. For samples with higher than expected $\mathrm{Ca}^{2+}$ concentrations, conservative aragonite saturation values were calculated based on measured $\mathrm{Ca}^{2+}$ concentrations (Table 1).

\section{Materials and methods}

The area of influence of the low-pH waters was determined by direct measurement of physiochemical parameters either in situ (temperature, salinity, and $\mathrm{pH}$ ) or from discrete water samples (DIC, TA, salinity, and nutrients). In the case of circular seeps (see Fig. 1e), water samples were collected at $0.25-\mathrm{m}$ intervals along transects placed at right angles and intersecting over the center of each ojo: transects were at least $4 \mathrm{~m}$ from the ojo center in all directions. In the case of fractures (see Fig. 1a, d), samples were taken along one long transect (up to $10 \mathrm{~m}$ ) following the fracture line, and samples were also collected at 5 or more cross-transect lines perpendicular to the main fracture. Divers collected the water in syringes that were immediately transported to a waiting boat for filtration, poisoning (for DIC and TA), and storage using standard operating procedures outlined by Dickson et al. (2007).

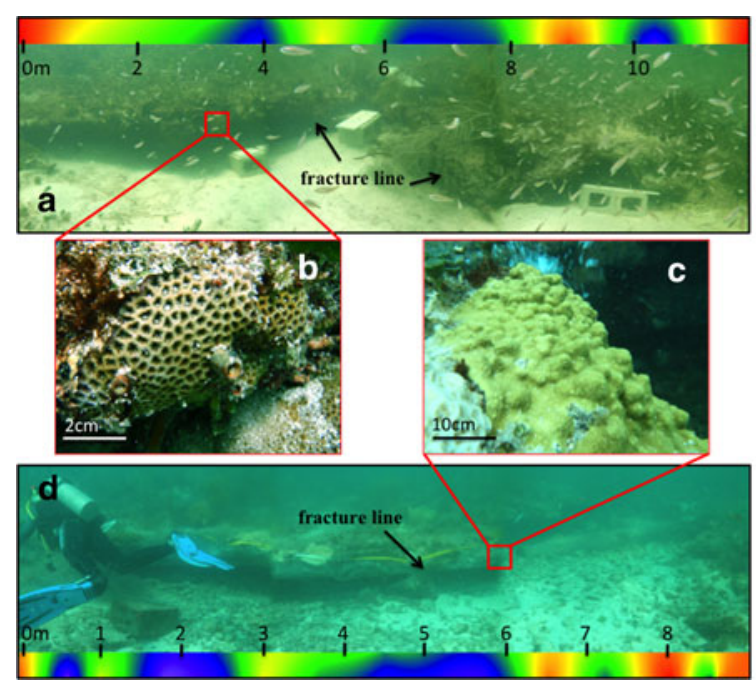

Fig. 1 Saturation state distribution along select transects in the vicinity of three different ojos with pictures of corals situated around the ojo centers. The saturation state $\left(\Omega_{\text {arag }}\right)$ is shown as a contour image (plotted in Surfer ${ }^{\circledR}$ ), and the colors represent the range of saturation levels from blue (low saturation) to red (supersaturation). The contour image gives a visual representation of what the saturation state may look like along a sample transect line. The saturation $\left(\Omega_{\text {arag }}\right)$ values were determined based upon discreet water samples taken at 0.25 -m intervals (up to 36 samples per transect). Distance along the

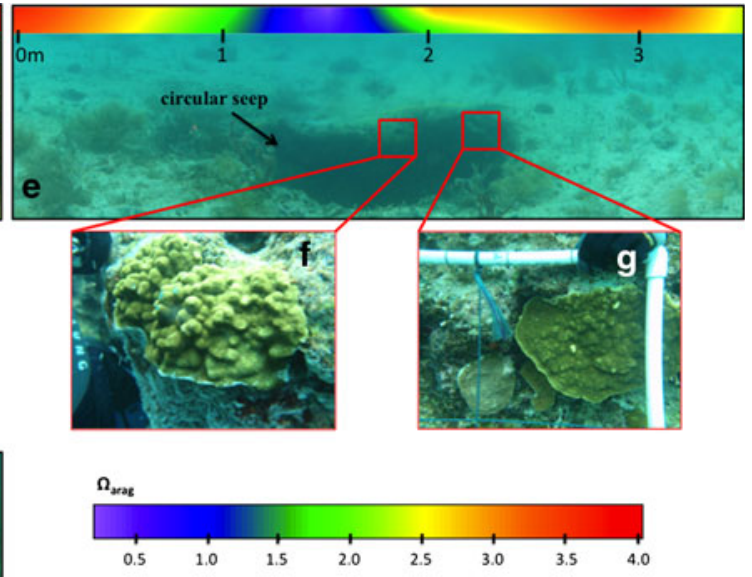

transect line is noted in the contour image in meters ( $X$ axis), and the $Y$ axis represents $0.25 \mathrm{~cm}$. The coral images give examples of where the corals were found along these transect lines. a (Ojo Laja) and d (Ojo Fractura) are examples of large "fractures," while e (Ojo de Agua) is a large circular "seep". Calcifying coral species including Siderastrea radians $(\mathbf{b})$ and Porites astreoides $(\mathbf{c}, \mathbf{f})$ were found in undersaturated and low saturation water at all 10 ojos sampled. Six additional species including Agaricia (alongside Porites) $\mathbf{g}$ lived in supersaturated waters where $\Omega_{\text {arag }}>2.5$ 
Ecological surveys commenced after the water was sampled to reduce the risk of contamination or mechanical mixing by divers. Data from benthic biota (identity, density, and size) around each ojo were scored in contiguous $0.25 \times 0.25 \mathrm{~m}$ quadrats along the transect lines as described above (ESM Fig. 5S). Particular care was taken to record coral size and position within each transect.

DIC samples were analyzed in triplicates on a model $5011 \mathrm{CO}_{2}$ Coulometer (UIC, Inc), and care was taken to ensure that the samples were not exposed to the atmosphere prior to analysis (measurement error of $\pm 3 \mu \mathrm{M}$ ). The TA samples were run using an automated, open-cell, potentiometric titration procedure (measurement error $\pm 2 \mu \mathrm{M}$ ). Certified $\mathrm{CO}_{2}$ reference material (Batch 90) from the Andrew Dickson lab at UC San Diego was used to ascertain the quality of results obtained. Nutrient $\left(\mathrm{NO}_{3}{ }^{-}, \mathrm{NO}_{2}{ }^{-}\right.$, $\mathrm{NH}_{4}{ }^{+}, \mathrm{Si}$, and $\mathrm{PO}_{4}^{-3}$ ) analyses were run on a flow injection autoanalyzer (FIA, Lachat Instruments Model QuickChem $8000)$ using standard procedures. $\mathrm{Ca}^{2+}$ concentrations were determined via ICP-OES (Perkin Elmer Optima 4300) using standard dilution and internal spikes. The carbonate system (carbonate saturation) was calculated from the measured parameters (DIC, TA, $\mathrm{pH}$, temperature, salinity, $\mathrm{Ca}$, and nutrients) using the program $\mathrm{CO}_{2} \mathrm{Sys}$ (see Table 1).

Total coral area was calculated based on observed measurements from the field and reported as area coverage per $25 \mathrm{~cm}^{2}$. Due to differences in the area influenced by the ojo waters between sites (e.g., discharge flux was different at each ojo as was the area impacted by the discharging water), statistical analyses were conducted for data grouped based on the calculated saturation state. Samples were grouped by "supersaturation" $(\Omega>2.5)$, "low saturation" $(1<\Omega<2.5)$, and "undersaturation" $(\Omega<1)$ at each site.

\section{Results}

At all 10 ojos sampled, the center of each discharge point (Fig. 1) was undersaturated with respect to aragonite (i.e., $\Omega_{\text {arag }}<1$ ), and low saturation conditions (i.e., $\Omega_{\text {arag }}<2.5$ ) were seen close to the discharge area. Saturation values increased rapidly with distance from the ojo center (Fig. 1). While waters generally reached saturation $\left(\Omega_{\text {arag }}=1\right)$ within $0.5 \mathrm{~m}$ of the center of discharge, saturation values below 2.5 were observed up to $2 \mathrm{~m}$ from the ojo (ambient $\Omega$ in the lagoon was 3.60; see Fig. 1). Salinities at the ojo center were always lower than ambient due to the brackish discharge, but not lower than 25. Despite these low salinities, $\mathrm{Ca}^{2+}$ concentrations were generally somewhat higher than expected from simple dilution of seawater to the measured salinities, because $\mathrm{Ca}^{2+}$ was added to the groundwater from the dissolution of limestone (ESM Fig. 3S). DIC and TA concentrations were highest at the
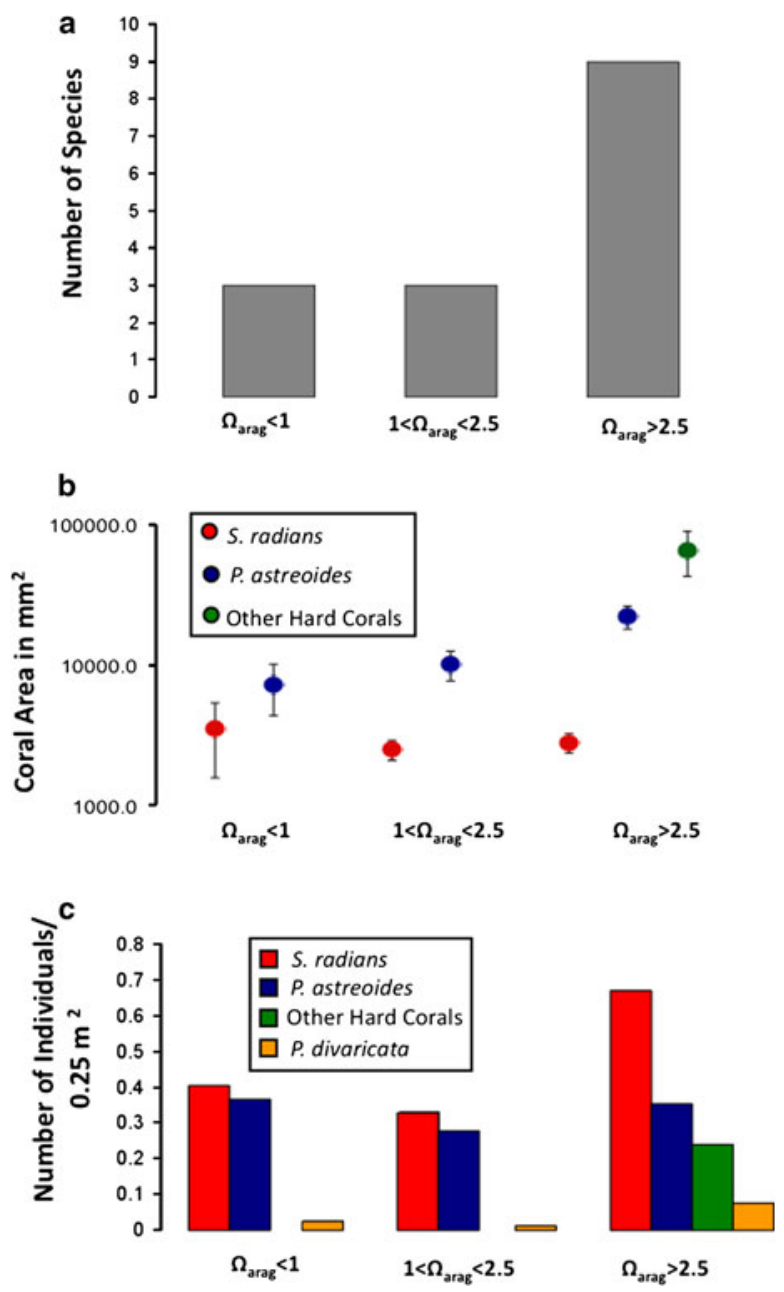

Fig. 2 a Number of species as a function of saturation state. No "other hard corals" (Diploria, Montipora, Montastrea, Agaricia, Porites, and Favia sp.) were found in low saturation or undersaturated $(\Omega<2.5) \quad$ waters. Species richness increased significantly $(P<0.001)$ with increasing saturation state. b Coral size as a function of saturation state for the different species. Average values for each group are reported, and error bars indicate standard error. Corals were grouped into 3 classes based on the saturation of the water in which they were observed: $\Omega<1(n=31) ; 1<\Omega<2.5$ $(n=72)$; or $\Omega>2.5(n=172)$. No significant differences in size were observed in colonies of Siderastrea radians; however, colonies of Porites astreoides were significantly larger in supersaturated $(\Omega>2.5)$ water when compared to Porites astreoides colonies in low saturation and undersaturated water $(P=0.05)$. Porites divericata colonies were omitted due to the rarity of their occurrence in both undersaturated and supersaturated water. Although comparing coral colony size for assemblages composed of different species is complicated by species-related morphology and growth rates, we also report the average size of all species found in supersaturated waters to provide qualitative information regarding coral growth outside of the springs. We note that the average size of all species found in supersaturated waters was significantly larger $(P<0.03)$ than the average size of corals found where $\Omega<2.5$. c Number of coral colonies per unit area as a function of saturation state. Results are normalized to per unit area $\left(0.25 \mathrm{~m}^{2}\right)$ to account for differences in area sampled between groups. The total (i.e., all species combined) number of coral colonies per unit area increased significantly with saturation state $(P<0.0001, N=275)$ 
center of discharge and decreased with distance from the discharge site. TA and DIC were correlated $\left(R^{2}=0.86\right)$ (ESM Fig. 4S). Dissolved nutrient (nitrate, ammonium, phosphate, and silica) concentrations ranged from approximately 2-10 times ambient (Derse et al. 2008).

Calcifying organisms such as corals, coralline algae, and calcifying macroalgae were often present in undersaturated or low saturation waters close to the ojos. Here, we focus on calcifying corals, which were present where $\Omega_{\text {arag }}<2.5$ at all 10 ojos sampled. Only three scleractinian species (Porites astreoides, Porites divaricata, and Siderastrea radians) and one hydrozoan "fire coral" (Millepora alcicornis) were observed where $\Omega_{\text {arag }}<2.5$. All of these species have aragonitic skeletons. Another six scleractinian coral species (Diploria, Montipora, Montastraea, Agaricia, Porites, and Favia) were present near the ojos, but only where the water saturation was above $2.5\left(\Omega_{\text {arag }}>2.5\right)$. These distributions may be evidence that certain calcifying coral species are more tolerant of low saturation waters than other species, with potential implications for differential survival under future $\mathrm{CO}_{2}$ projections. A goodness-of-fit analysis indicates that the number of species (i.e., species richness) increased significantly as saturation values increased with distance from the ojo centers $(P<0.0001$; Fig. 2).

To determine whether saturation state affected the sizes of coral colonies living near the ojos, we compared colony sizes (measured as the plane area) of the three scleractinian species in undersaturated $\left(\Omega_{\text {arag }}<1\right)$ plus low saturation $\left(1<\Omega_{\text {arag }}<2.5\right)$ waters with sizes of the same species at control sites in supersaturated waters where $\Omega_{\text {arag }}>2.5$ (close to, but outside the influence of discharge). The size of Siderastrea radians colonies did not differ significantly between the saturation levels; however, Porites astreoides colonies in undersaturated and low saturation waters near ojos were significantly smaller than Porites astreoides colonies in supersaturated water (ANOVA, $P=0.05$; Fig. 2). We then compared the sizes of all colonies present where $\Omega<2.5$ to the sizes of all coral species found in supersaturated waters and found that the colonies in less saturated waters were also significantly smaller (ANOVA, $P=0.03$; Fig. 2). We note that this last comparison provides only a qualitative analysis, as the comparison is across species with different morphologies. Combined, our data suggest that as saturation levels approached maximum ambient values, both the number of species present and the average size of individual colonies of Porites astreoides increased significantly and that in general the coral colonies tend to be larger away from the ojo.

When abundances (number of colonies) of Porites astreoides and Siderastrea radians in low saturation $\left(\Omega_{\text {arag }}<2.5\right)$ and supersaturated $\left(\Omega_{\text {arag }}>2.5\right)$ waters were compared, the densities (number of colonies per $0.25 \mathrm{~cm}^{2}$ ) of these individual species did not vary with saturation state. However, for all species combined, the densities were significantly greater away from the ojos (goodness-of-fit; $P<0.001$; Fig. 2). This is attributed to the increase in species number as supersaturation was reached.

\section{Discussion}

Ecological surveys at the ojo sites indicate that certain scleractinian coral species can grow in undersaturated conditions. Thus, these species may be more tolerant of low-pH and low aragonite saturation conditions, and hence more resistant than other species when exposed to changing oceanic $\mathrm{pH}$ and carbonate saturation. However, the number of species that can survive at these low saturation conditions is limited compared with the species richness of the surrounding area. These findings are generally consistent with those of Fabricius et al. (2011) from $\mathrm{CO}_{2}$ vents in Papua New Guinea, where the diversity and abundance of structurally complex corals was reduced threefold at low pH, yet Porites corals were still found at $\mathrm{pH}$ below 7.7 and aragonite saturation of 2.9. At Puerto Morelos, the conditions are more extreme as the water is often undersaturated or has much lower saturation values than 2.9, yet Porites astreoides and Siderastrea radians corals are still abundant. Therefore, the Puerto Morelos site demonstrates that certain coral species may tolerate extreme acidification events and still maintain their ability to calcify. While we did not measure calcification rates during this study, we note that the ojos are part of a complex and elaborate underground conduit system that has developed over millennia in this karstic terrain. The seepage at these sites has therefore been continuous for an extended period of time compared with the average age of coral colonies. Thus, the corals settled, calcified, and the colonies grew within the plume of low-pH groundwater discharge. This is different than the more ephemeral volcanic vent sites, and therefore the ojos represent areas where the ecosystem had ample time to adapt and evolve exposed to low-pH conditions.

Although the coral species found at the ojo sites ( $S$. radians, $P$. astreoides, and $P$. divaricata) all occur on reef structures, they are rarely major contributors to the framework of the Meso-American Barrier Reef: thus, while their presence is encouraging when considering the future of these specific scleractinian species, there are severe implications for the future of reef ecosystems and the many organisms that rely on structurally complex corals to build the reef framework. Specifically, our data suggest that as seawater saturation nears 2.5, today's larger, dominant, framework-building corals of the Meso-American Reef (e.g., Acropora and Montastraea), may be replaced by smaller, patchily distributed colonies of only a few species. 
While only a limited number of coral species live in areas exposed to the low-pH groundwater, their presence in undersaturated waters raises interesting questions. Physiological and/or genetic adaptations allowing corals and other calcifying organisms to persist under low saturation, low$\mathrm{pH}$ conditions are largely unknown and are currently under investigation. One suggestion is that the energy allocated to calcification in such conditions may come at the expense of other metabolic activities and result in lower growth rates (Atkinson et al. 1995; Jokiel et al. 2008; Cohen and Holcomb 2009); another idea is that high nutrient concentrations could provide energetic resources that may offset deleterious effects of high $\mathrm{CO}_{2}$ (Jokiel et al. 2008; Cohen and Holcomb 2009). Laboratory experiments with Astrangia, Occulina, Porites, Montipora, and Favia sp. show that while calcification rates were reduced under low saturation $(\Omega \sim 1.5)$ conditions, the addition of inorganic nutrients or food under the same low saturation conditions enabled the corals to maintain $75-100 \%$ of their calcification rates (Langdon and Atkinson 2005; Ries et al. 2009; Cohen and Holcomb 2009; Holcomb et al. 2009). These ideas are consistent with our field observations that certain coral species may survive in undersaturated waters when nutrient concentrations are high (ojo waters had 2-10 times higher nutrient concentrations than surrounding water). The interplay of nutrient availability, low saturation conditions, and calcification in corals should be further investigated under natural conditions as this may be important for predicting future coral distribution and survival.

Another potential explanation for the survival of some coral species in the immediate vicinity of the ojos is that daily or seasonal fluctuations in discharge may periodically expose the corals to ambient waters with high saturation levels. Our samples were taken on three field trips over a 15-month period and were monitored continuously over 2 months, and pH levels were nearly always low at ojo sites, where the three tolerant scleractinian species were present (Hofmann et al. 2011). However, it is possible that the groundwater discharge fluxes do vary over time scales we have not captured, and that these corals experience intermittent relief from low-pH, low aragonite saturation waters. Semi-permanent sensors installed over a whole year will enable us to determine the consistency of saturation levels around the corals. If fluctuations in discharge do impact saturation conditions, we will be able to estimate possible response thresholds for the coral species living nearest to the ojo centers (e.g., minimum duration or fraction of time spent in supersaturated conditions required for corals to survive).

In natural environments, it is not possible to entirely exclude the impact of other variables, and for the ojos specifically the impact of lower salinity, on the observed coral distribution. However, previous studies suggest that many species are able to withstand osmotic stress with limited harmful effects when exposed to lower than ambient salinities (Coles and Jokiel 1978; Hoegh-Guldberg and Smith 1989; Xiubau et al. 2009). In fact, Coles and Jokiel (1978) showed that salinities as low as 25 ppt in themselves were insufficient to have any negative impacts on Montipora sp., a coral found in abundance along the Puerto Morelos coast. Here, we only present data from ojos with salinities consistently above 25 ppt. As Montipora and many other corals were commonly observed at the control sites, yet not within the low saturation zones, this suggests that salinity itself is insufficient to explain the observed distribution patterns. While the impact of multiple stressors (i.e., high temperature, light, and/or sedimentation) can compound the salinity factor and cause negative responses across species (Coles and Jokiel 1978; Hoegh-Guldberg and Smith 1989; Lirman and Manzello 2009; Xiubau et al. 2009), these discharge sites actually experience lower than ambient temperatures while light and sedimentation levels remain the same at the ojos and at the control sites. Therefore, by only including data from ojos that have salinities consistently higher than $25 \mathrm{ppt}$, we have attempted to control for, if not entirely negate, the impact of salinity on coral distribution found at Puerto Morelos.

This work illustrates that while the effects of ocean acidification on coral reefs and other calcifying organisms may be severe, the impacts will differ considerably across various species and ecosystems and some calcifying corals given the right condition will continue to grow and calcify. It is possible, therefore, that the ocean acidification scenario will result in an ecosystem shift along the Mesoamerican Barrier Reef, in which today's frame-building colonies are replaced by more tolerant species such as Porites and Siderastrea. The decrease in species richness observed when $\Omega_{\text {arag }}<2.5$ indicates that an acidified ocean may change the composition and species diversity of reefs, which has the potential to impact the ecosystem services they provide. This work gives a first insight as to the highly adaptive nature of certain reef species; however, it also calls for the future need to increase protection in areas that might serve as ecological refuges for corals that may have adapted to survival in low-pH, low saturation waters.

Acknowledgments We give special thanks to the water quality team at CICY, and employees of CONANP, for their help with field work coordination and use of their boats. We are indebted to $\mathrm{N}$. Crook, B. Allen, K. Roberts, Adrien LeCossec, and J. Logan for their help with diving and field work, and to R. Franks for technical assistance in the laboratory. This research was funded by NSF OCE1040952 and UC-Mexus grants to AP.

Open Access This article is distributed under the terms of the Creative Commons Attribution Noncommercial License which permits any noncommercial use, distribution, and reproduction in any medium, provided the original author(s) and source are credited. 


\section{References}

Anthony KRN, Kline DI, Diaz-Pulido G, Dove S, Hoegh-Guldberg O (2008) Ocean acidification causes bleaching and productivity loss in coral reef builders. Proc Natl Acad Sci USA 105: 17442-17446

Atkinson MJ, Carlson B, Crow GL (1995) Coral growth in highnutrient, low-pH seawater: a case study of corals cultured at the Waikiki Aquarium, Honolulu, Hawaii. Coral Reefs 14:215-223

Beddows PA, Smart PL, Whitaker FF, Smith SL (2002) Density stratified groundwater circulation on the Caribbean coast of the Yucatan peninsula, Mexico. Frontiers of Karst Research: Karst Waters Institute Special Publication 7:129-134

Caldeira K, Wickett ME (2005) Ocean model predictions of chemistry changes from carbon dioxide emissions to the atmosphere and ocean. J Geophys Res 110, C09S04

Carruthers TJB, van Tussenbroek BI, Dennison WC (2005) Influence of submarine springs and wastewater on nutrient dynamics of Caribbean seagrass meadows. Estuar Coast Shelf Sci 64: 191-199

Cigliano M, Gambi MC, Rodolfo-Metalpa R, Patti FP, Hall-Spencer JM (2010) Effects of ocean acidification on invertebrate settlement at volcanic $\mathrm{CO}_{2}$ vents. Mar Biol 157:2489-2502

Cohen AL, Holcomb M (2009) Why corals care about ocean acidification: uncovering the mechanism. Oceanography 22:118-127

Coles SL, Jokiel PL (1978) Synergistic effects of temperature, salinity and light on the hermatypic coral Montipora verrucosa. Mar Biol 49:187-195

Derse E, Knee K, Rebolledo-Vieyra M, Ibarra MM, Grey E, Paytan A (2008) Submarine groundwater discharge and nutrient additions to the Puerto Morelos coast of the Yucatan Peninsula. AGU Proceedings: OS51D-1281

Dias BB, Hart MB, Smart CW, Hall-Spencer JM (2010) Modern seawater acidification: the response of foraminifera to high $\mathrm{CO}_{2}$ conditions in the Mediterranean Sea. Journal of the Geological Society 167:843-846

Dickson AG, Sabine CL, Christian JR (eds) (2007) Guide to best practices for ocean CO2 measurements. PICES Special Publication 3, p191

Doney SC, Balch WM, Fabry VJ, Feely RA (2009) Ocean acidification: a critical emerging problem for the ocean sciences. Oceanography 22:16-25

Fabricius KE, Langdon C, Uthicke S, Humphrey C, Noonan S, De'ath G, Okazaki R, Muehllehner N, Glas MS, Lough JM (2011) Losers and winners in coral reefs acclimatized to elevated carbon dioxide concentrations. Nature Climate Change 1:165-169

Fine M, Tchernov D (2007) Scleractinian coral species survive and recover from decalcification. Science 315:1811

Hall-Spencer JM, Rodolfo-Metalpa R, Martin S, Ransome E, Fine M, Turner SM, Rowley SJ, Tedesco D, Buia MC (2008) Volcanic carbon dioxide vents show ecosystem effects of ocean acidification. Nature 454:96-99

Hoegh-Guldberg O, Smith GJ (1989) The effect of sudden changes in temperature, light and salinity on the population density and export of zooxanthellae from the reef corals Stylophora pistillata Esper and Seriatopora hystrix Dana. J Exp Mar Biol Ecol 129:279-303
Hofmann GE, Smith JE, Johnson KS, Send U, Levin LA, Micheli F, Paytan A, Price NN, Peterson B, Takeshita Y, Matson PG, Crook ED, Kroeker KJ, Gambi MC, Rivest EB, Frieder CA, Yu PC, Martz TR (2011) High frequency dynamics of ocean pH: a multi ecosystem comparison. PLoS ONE (in press)

Holcomb MC, McCorkle DC, Cohen AL (2009) Long-term effects of nutrient and $\mathrm{CO} 2$ enrichment on the temperate coral Astrangia poculata (Ellis and Solander, 1786). J Exp Mar Biol Ecol 386:27-33

Jokiel PL, Rodgers KS, Kuffner IB, Andersson AJ, Cox EF, Mackenzie FT (2008) Ocean acidification and calcifying reef organisms: a mesocosm investigation. Coral Reefs 27:473-483

Langdon C, Atkinson MJ (2005) Effect of elevated $\mathrm{pCO}_{2}$ on photosynthesis and calcification of corals and interactions with seasonal change in temperature/irradiance and nutrient enrichment. J Geophys Res 110, C09S07. doi: 10.1029/2004JC002576

Lirman D, Manzello D (2009) Patterns of resistance and resilience of the stress-tolerant coral Siderastrea radians (Pallas) to suboptimal salinity and sediment burial. J Exp Mar Biol Ecol 369:72-77

Mehrbach C, Culberson CH, Hawley JE, Pytkowicz RM (1973) Measurements of the apparent dissociation constants of carbonic acid in seawater at atmospheric pressure. Limnol Oceanogr 18:897-903

Orr JC, Fabry VJ, Aumont O, Bopp L, Doney SC, Feely RA, Gnanadesikan A, Gruber N, Ishida A, Joos F, Key RM, Lindsay K, Maier-Reimer E, Matear R, Monfray P, Mouchet A, Najjar RG, Plattner GK, Rodgers KB, Sabine CL, Sarmiento JL, Schlitzer R, Slater RD, Totterdell IJ, Weirig MF, Yamanaka Y, Yool A (2005) Anthropogenic ocean acidification over the $21^{\text {st }}$ century and its impact on calcifying organisms. Nature 437: 681-686

Pierrot D, Lewis E, Wallace DWR (2006) MS excel program developed for $\mathrm{CO} 2$ system calculations. ORNL/CDIAC-105a Carbon Dioxide Information Analysis Center, Oak Ridge National Laboratory, U S Department of Energy

Riebesell U, Fabry VJ, Hansson L, Gattuso JP (2010) Guide to best practices for ocean acidification research and data reporting. Luxembourg: Publications Office of the European Union, Luxembourg

Ries JB, Cohen AL, McCorkle DC (2009) Marine calcifiers exhibit mixed responses to $\mathrm{CO} 2$ induced ocean acidification. Geology 37:1131-1134

Rodolfo-Metalpa R, Lombardi C, Cocito C, Hall-Spencer JM, Gambi MC (2010) Effects of ocean acidification and high temperatures on the bryozoan Myriapora truncata at natural $\mathrm{CO}_{2}$ vents. Mar Ecol 31:447-456

Ruiz-Renteria F, van Tussenbroek BI, Jordan-Dahlgren E (1998) Puerto Morelos, Quintana Roo, Mexico. In CARICOMP: Caribbean coral reef, seagrass, and mangrove sites. Special Report UNESCO, Paris, pp 57-66

van Tussenbroek BI (1995) Thalassia testudinum leaf dynamics in a Mexican Caribbean coral reef lagoon. Mar Biol 122:33-40

Xiubau L, Hui H, Jiansheng L, Liangmin H, Junde D (2009) Effects of the multiple stressors high temperature and reduced salinity on the photosynthesis of the hermatypic coral Galaxia fascicularis. Acta Ecol Sin 29:155-159 